\title{
Avulsion fracture of the anterior cruciate ligament in a 9-year-old child
}

\author{
Ozkan Kose, ${ }^{1}$ Selahattin Ozyurek, ${ }^{2}$ Ferhat Guler, ${ }_{1}^{1}$ Kerem Canbora ${ }^{3}$
}

${ }^{1}$ Department of Orthopaedics and Traumatology, Antalya Education and Research Hospital, Antalya, Turkey ${ }^{2}$ Department of Orthopaedics and Traumatology, Aksaz Military Hospital, Mugla, Turkey

${ }^{3}$ Department of Orthopaedics and Traumatology, Haydarpasa Numune Education and Research Hospital, Istanbul, Turkey

Correspondence to Dr Selahattin Ozyurek, fsozyurek@yahoo.com
To cite: Kose O, Ozyurek S, Guler F, et al. BMJ Case Rep Published online: [please include Day Month Year] doi:10.1136/bcr-2013009426

\section{DESCRIPTION}

A 9-year-old girl sustained an injury to her right knee during sliding on the playground. Immediately after the injury, she felt a sharp pain in her knee and she was unable to walk. On physical examination there was marked knee effusion without ecchymosis or deformity and the patient was keeping her knee in slight flexion. Both flexion and extension of the knee were painful. Knee ligamentous examination could not be performed due to intentional guarding. Plain radiographs demonstrated an intra-articular bone fragment in the intercondylar notch (figure 1A,B). An MRI examination revealed completely displaced avulsion fracture of the anterior cruciate ligament (ACL; figure 1C,D). Open reduction and internal fixation with two compressive screws were performed with limited arthrotomy. At the final follow-up 9 months after the injury, the fracture healed without any sign of knee instability (figure 2).

Avulsion fractures of tibial spine also called as tibial eminence fracture or ACL avulsion fracture is an uncommon injury usually seen more in children than in adults. In children it is associated with forced flexion and in adults it occurs due to hyperextension injuries. ${ }^{12}$

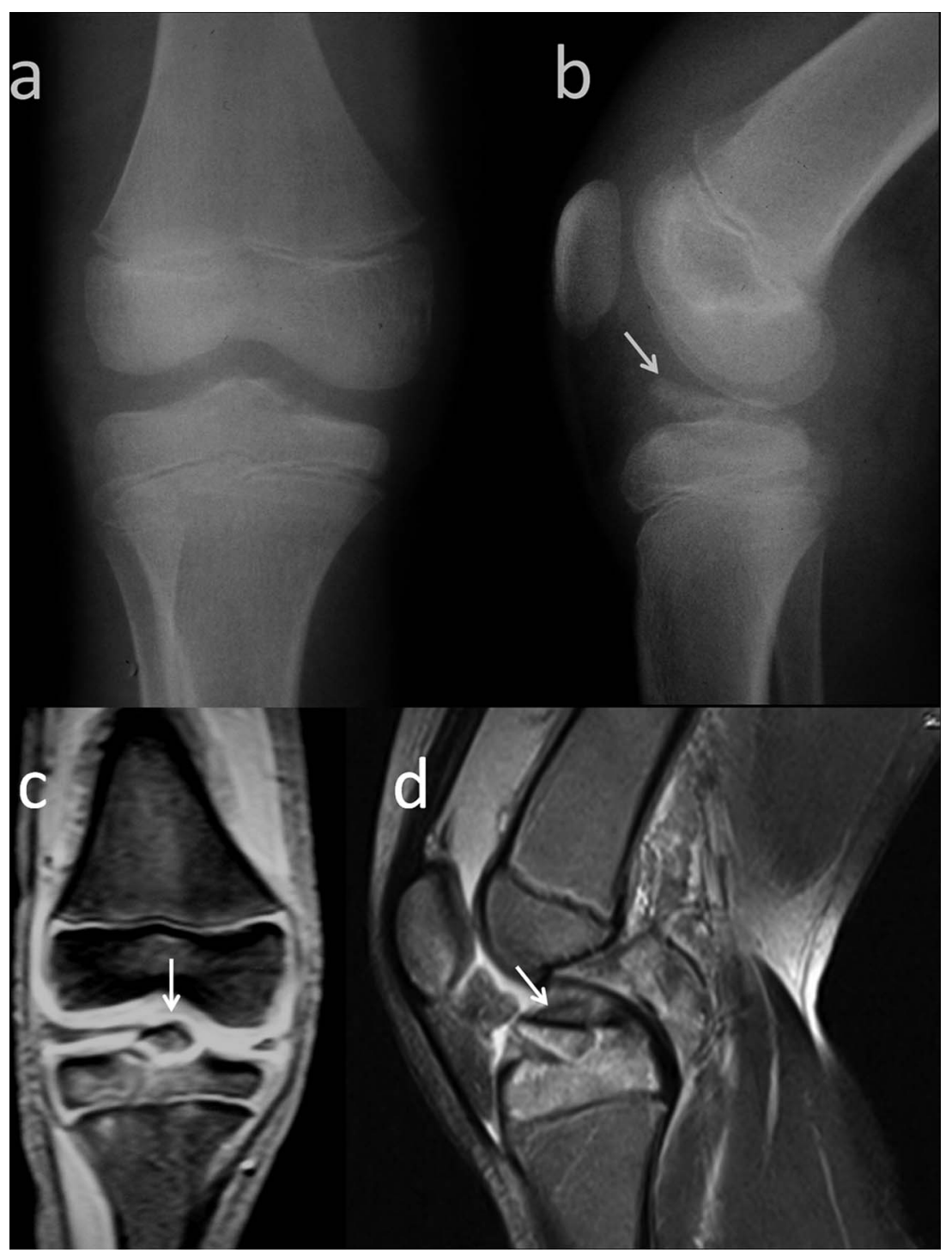

Figure 1 (A) Anteroposterior and (B) lateral radiographs of right knee depicting an intra-articular fracture fragment in the intercondylar notch (arrow); (C and D) MRI showing a bone fragment avulsed from the tibia (arrow) with an adjacent marrow oedema. 


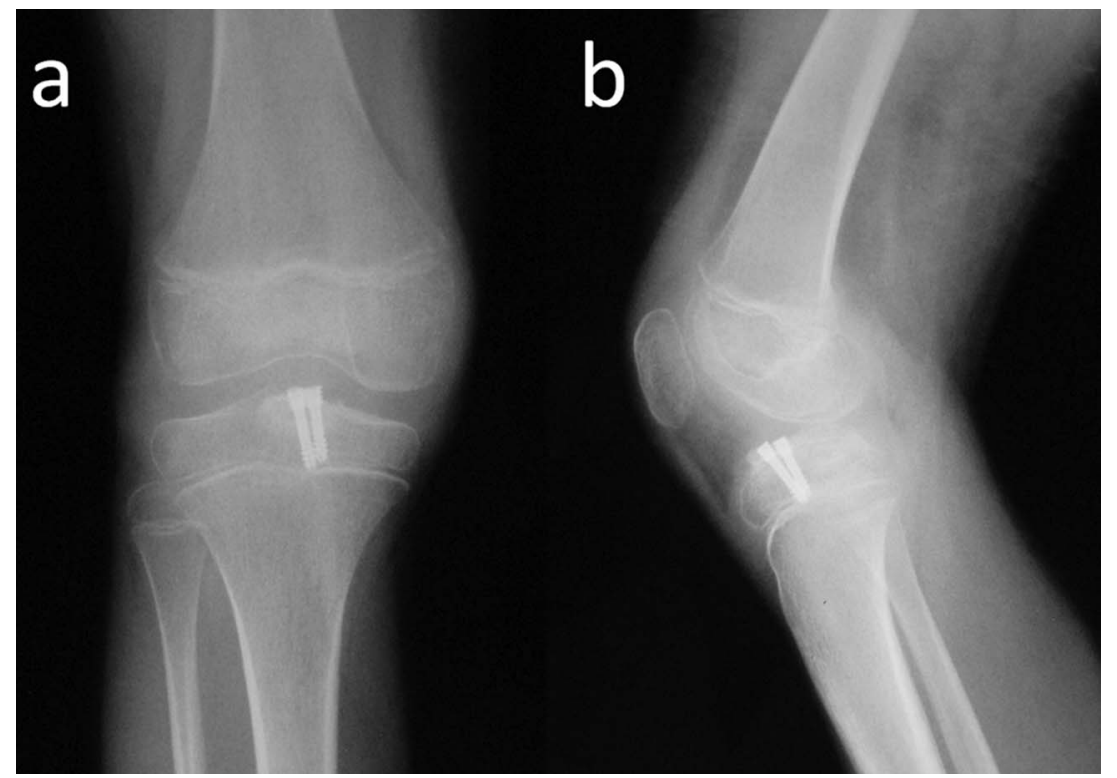

Figure 2 (A) Anteroposterior and (B) lateral views of the patient's knee at 9-month follow-up.

Standard imaging for ACL tibial spine avulsion fractures include anteroposterior and lateral radiographs. The fracture is best seen on the lateral radiograph. An MRI is useful to determine the site of origin of the bone fragment and to assess the associated soft tissue injuries. ${ }^{1}{ }^{2}$ In the elderly, it can be confused chondrocalcinosis related with calcium pyrophosphate disease. $^{3}$

The Meyers and McKeever classification describes three types of ACL avulsion fracture injuries. Type IV was later added by Zariczynj to include comminuted fractures of tibial spine. Type I - undisplaced fracture of tibial eminence, type II-anterior segment of fragment is elevated but hinged, type III-completely displaced fracture and type IV-completely displaced and comminuted fragment. Type I can be managed conservatively but anatomical reduction and internal fixation were required for types II-IV. ${ }^{2}$

\section{Learning points}

Although most anterior cruciate ligament tears involve the midsubstance of the ligament, avulsion of its tibial attachment occurs in a minority of cases and is more common in children than adults.

- Anterior cruciate ligament avulsion fracture is best seen on lateral knee radiograph however MRI delineates the site of origin of the bone fragment and associated soft tissue injuries.

- Early diagnosis and treatment of this knee joint abnormality may help diminish long-term disability.
Contributors All authors are included in writing and controlling the manuscript. Competing interests None.

Patient consent Obtained.

Provenance and peer review Not commissioned; externally peer reviewed.

\section{REFERENCES}

1 Gottsegen CJ, Eyer BA, White EA, et al. Avulsion fractures of the knee: imaging findings and clinical significance. Radiographics 2008;28:1755-70.

2 Sapre V, Bagaria V. In: Bagaria V, ed. Tibial spine avulsion fractures: current concepts and technical note on arthroscopic techniques used in management of these injuries, regional arthroscopy. ISBN: 978-953-51-1044-6, InTech, doi: 10.5772/54967

3 Kaushik S, Erickson JK, Palmer WE, et al. Effect of chondrocalcinosis on the MR imaging of knee menisci. Am J Roentgenol 2001;177:905-9. 
Copyright 2013 BMJ Publishing Group. All rights reserved. For permission to reuse any of this content visit http://group.bmj.com/group/rights-licensing/permissions.

BMJ Case Report Fellows may re-use this article for personal use and teaching without any further permission.

Become a Fellow of BMJ Case Reports today and you can:

- Submit as many cases as you like

- Enjoy fast sympathetic peer review and rapid publication of accepted articles

- Access all the published articles

- Re-use any of the published material for personal use and teaching without further permission

For information on Institutional Fellowships contact consortiasales@bmjgroup.com

Visit casereports.bmj.com for more articles like this and to become a Fellow 